\title{
GREGOR VOGT-SPIRA
}

Philipps Universität Marburg

e-mail:vogtspira@staff.uni-marburg.de

\section{LATIN: BACK TO THE FUTURE? \\ SOME REFLECTIONS ON LATIN AND LITERACY IN THE DIGITAL AGE}

\begin{abstract}
Vogt-Spira Gregor, Latin: Back to the Future? Some Reflections on Latin and Literacy in the Digital Age (Lacina: powrót do przyszłości? Kilka refleksji nad lacina i kwestiami literackimi w epoce digitalizacji).

This paper argues that Latin meets the challenges of this day and age so that its preservation actually has a well-founded place within European countries and societies. The argumentation starts by the observation that Latin gathers a number of additional values as an alterity training, a cognitive training, a linguistic training or a socially integrative effect, values, which are remarkably not bound to a specific culture. Above all, digitization and the modern cybernetic world is seen as a central challenge, digitization with its enormous quantitative increase in reading and writing activity also transforms the user profile in a way that complements it, a factor to which educational institutions have yet to come up with a conclusive response. Referring to this development, Latin has the particular significance of imparting the standards of an elaborate written form into the composition and decoding of texts. Furthermore, Latinity itself is considered to be one of the key factors that have shaped modern-day Europe, and the later Latin-language literature is seen to be a comprehensive component of each country's respective national literature and culture. To conclude, the ancient European custom is brought into focus that, practically, antiquity serves as a vehicle for legitimizing modernization.
\end{abstract}

Keywords: Latin; digitization; antiquity; modernization; cultural memory.

Changes to the education system are normally justified on the grounds that we must do more to accommodate present day needs. Regardless of how the specifics of such needs are determined, Latin seems more often than not to belong on the side of tradition, the side persistently targeted by reforms.

This has not always been the case, however. Over the last 500 years, Latin has in many ways been on the side of modernity and has been considered a carrier of innovation. Here are but a few examples worth recalling: Renaissance humanism understood that the practice of referring back to antiquity marked the 
emergence of a new era, and with this outlook spread in various stages across Europe; in the $16^{\text {th }}$ century, people went so far as to assert that whoever did not have a sufficient grasp of Latin was a foreigner in their mother tongue. ${ }^{1}$ Into the $18^{\text {th }}$ century, one finds the view that the different European nations owed their cultural status to the study of the great ancient writers: those who were not as advanced and wanted to close the gap had to thus heed the writers of antiquity. ${ }^{2}$ Lastly, the education reforms of the $19^{\text {th }}$ century assigned Greek and Latin a key role, bestowing on them such a dominant position that dissent was all but inevitable.

In reality, the revaluation of Latin within school curriculums always involves objections and counter-reactions as well, for which the concrete practice of the Latin instruction often enough provides clear grounds. Yet regardless of all these counter-reactions, knowledge of Latin in European countries has remained remarkably stable throughout the entire modern era. One could almost speak of a cultural bracket that provides "Roman" Europe with a deep structure that remains effective to this day. ${ }^{3}$

Nevertheless, even though more people (in pure quantitative terms) in European countries are indeed learning (or have learned) Latin than ever before due to the expansion of education, the question as to why one should learn Latin instead of, say, natural science, economics or modern foreign languages does remain relevant. In the cases of, say, medicine or engineering, it seems apparent that they do accommodate present-day needs. Even so, one can reformulate that question accordingly: since the view that Latin was particularly suitable for addressing present-day needs prevailed over the course of many epochs of European history, it is thus worth examining: to what extent can Latin accommodate the needs of the early $21^{\text {st }}$ century?

It is a widely-spread conviction that learning Latin has an "added value" that transcends its status as an archaic and no longer spoken language. To quote an observation by the ethnologist Claude Lévi-Strauss as an example:

Those who criticize humanities instruction would be in the wrong if they deceived themselves into the thinking that the study of Greek and Latin was restricted to the ephemeral acquisition of the rudiments of dead languages. In that case it would serve little purpose. But through the language and texts - and this is something secondary school teachers know very well—an

\footnotetext{
${ }^{1}$ See J.C. Scaliger: Poetices libri septem, V 1, p. 42 Deitz - Vogt-Spira.

${ }^{2}$ See also Jaumann (1999: 335): "Der Prozeß fortschreitender Ausdifferenzierung, in dem in der frühen Neuzeit die europäischen Nationalkulturen ihre eigenen Identitäten ausbilden, hat sich bekanntlich zunächst, d.h. bis weit ins 18. Jahrhundert hinein, nicht von der griechisch-römischen Translationsbeziehung abgekoppelt, sondern diese im Sinne einer dritten Stufe im Prinzip weitergeführt."

${ }^{3}$ Leonhardt (2009: 146) speaks of a "Kommunikationsraum, der sich gegenüber anderen Kommunikationsräumen gerade dadurch abgrenzte, daß Latein die gemeinsam in allen Ländern verwandte Sprache war."
} 
intellectual method is made accessible to students, namely that of ethnography, which I like to call the technique of defamiliarization. ${ }^{4}$

Although the specific naming of that added value may depend on the perspective of the ethnologist, the fact that Latin is associated with a wealth of functions that go beyond the concrete context of antiquity is nevertheless one of Latin's most striking characteristics. Whether it is the experience of alterity, intellectual methods, insight into linguistic structures, or quite simply, cognitive training, the spectrum of functions ascribed to Latin is remarkably broad and diverse. One could assume that this is one of the reasons for its long-term impact.

Such an extraordinary continuity of more than 2,000 years is downright astounding. Essentially, this is owed to the fact that Latin has detached itself from fixed national, territorial or imperial classifications and has gained independence from a living language community. ${ }^{5}$ Therein lies the structural reason for its continuity beyond the end of the Roman Empire and for its gradual transformation into a universal means of communication. Of course, it would hardly have been possible without an institutional support structure: a considerable portion of this extraordinary persistence is due to the fact that the church adopted Latin as its official language.

An unavoidable epiphenomenon of such long-standing legitimacy is the recurring necessity to justify it. Accordingly, an abundance of strategies for defending legitimacy have evolved over time, each situated within specific culture-historical contexts. To compare them would indeed be highly instructive. In the second half of the $20^{\text {th }}$ century, this explanatory discourse was pursued with particular intensity, not least because of this saeculum's incisive break with tradition. If it has regained strength in recent decades, it seems to stem from a prevailing underlying conviction that one is standing amid comprehensive and profound changes occurring with great speed that are brought on by globalization and technological progress.

The discourse of legitimacy should not be continued at this particular juncture. It is not about providing the most comprehensive list of reasons that favor the study of Latin. Rather, we should reflect on how Latin can accommodate the needs of the present day so that its preservation actually has a well-founded place within European countries and societies.

4 “'Ceux qui critiquent l'enseignement classique auraient tort de s'y tromper : si l'apprentissage du grec et du latin se réduisait à l'acquisition éphémère des rudiments de langues mortes, il ne servirait pas à grand-chose. Mais - les professeurs de l'enseignement secondaire le savent bien - à travers la langue et les textes, l'élève s'initie à une méthode intellectuelle qui est celle-même de l'ethnographie, et que j'appellerais volontiers la technique du dépaysement" (Lévi-Strauss 1973: 320).

${ }^{5}$ See Leonhardt 2009: 91. Wilfried Stroh called Latin the "most successful language in the world“ for this very reason (2007: 15). 
As noted at the beginning of this paper, Latin is of topical relevance to a wealth of functions that fall outside its own subject categories of "Latin language and the culture of antiquity." From this perspective, Latin is considered a particularly efficient tool for promoting each specific objective. This type of argumentation is encountered primarily in didactic contexts, where the reason why a student should choose to study Latin rather than some other language (or even some other subject) is supposed to be made plausible. It seems noteworthy that these functional patterns of reasoning are not bound to a specific national culture, but are encountered with a certain regularity in various European countries as well as the United States. In the following, without claim to representativeness, a few examples from German, English and French-speaking areas are introduced as examples; it would be interesting to examine the main points generated by the discussion in Poland. ${ }^{6}$

One of the most frequently mentioned functions is the argument that Latin contributes to a better understanding of one's own language. In the Englishspeaking world, the focus in this respect is primarily on semantics: "The most commonly regarded benefit is the great improvement in the understanding of the English language. We derive approximately $60 \%$ of our English words, and $90 \%$ of those words consisting of more than two syllables, from Latin." argument has a significant role in French: "Studying Latin enables you to enrich your French vocabulary and to understand the orthography of certain words."

In the German-language discussion, in contrast, grammar and linguistic structure have a stronger priority. As a result of having to complete Latin in school, one gets a feel for the German language, and develops a sense of grammar and a general sense of specific linguistic structures. ${ }^{9}$ The argument is also encountered in French, ${ }^{10}$ and in the English-speaking world as well, where academic support for grammar is emphasized alongside semantics:

${ }^{6}$ Circumstances are somewhat different in Italy, where the close relation to Latin culture has been linguistically preserved. The fact that Italian ("volgare") was actually not considered different from Latin in the beginning is perhaps still prevalent today, since it is telling that almost none of the arguments given above are in evidence there and that the cultural aspect of learning Latin is, in any case, considered much more important than the linguistic one. Bettini (2017) gives a comprehensive discussion full of sprezzatura.

${ }^{7}$ Moore n.d.: 1 .

${ }^{8}$ See argument No 1 (Anonymous n.d.).

${ }^{9}$ See Jauch 2006: 146, quoted in Maier 2008: 29. The endorsement by this well-known TV host may be seen as indicative of a wide-spread belief.

${ }^{10} \mathrm{Cf}$. Drillon 2016, here argument No 4: "Comprendre une phrase, même simple, suppose donc que l'élève a compris ce qu'est la fonction d'un mot, et par conséquent qu'il a passé par cette phrase d'apprentissage. [...] Un élève qui sait employer la conjonction latine $u t$ sait toute la syntaxe, parce qu'il la voit exister sous ses yeux." 
English grammar is abstract and hidden because it is uninflected. It is unsystematic, unstructured, unreliable, and inconsistent. We are a loose and freedom loving people. We break the rules. The Romans were the most disciplined, structured, organized people in history and so was their language; their conjugations and declensions march in disciplined rows just like their legions. ${ }^{11}$

Complementing these native-speaker perspectives is a second argument that also recurs with regularity: Latin is a particularly suitable way to prepare for the study of other languages. This applies especially to Romance languages, yet also includes English due to its many words of Latin origin. In addition, the argument is used universally in a structurally cognitive sense: The distance of the Latin forces one to familiarize themselves with all of the relationships within linguistic structures. In doing so, one receives the best possible insight into the function of language. ${ }^{12}$

Finally, a third type of argumentation abstracts completely from the reference to specific languages. It situates cognitive abilities at the focal point, as the study of Latin has been acknowledged as beneficial to their development: "I consider this to be the most important reason of all: mental training. Latin is the most effective tool we have to develop and train the minds of the young. Not only does it cut in half the task of learning another language, it makes learning any subject easier." ${ }^{13}$ In German, this cognitive approach has a long, traceable history. Goethe thus spoke of it when referring to a statement by Luther: "The ancient languages are the sheaves, / into which the knife of the intellect is thrust." 14 Trivialized, the concept lives on in the sports metaphor " "exercise course' of the mind." 15 In any case, the topos that Latin stimulates analytical thinking and problem-solving skills is widespread. In the French-speaking world, another variant is encountered as well, one in which Latin's disciplining effect is strongly emphasized: "Latin (and to a lesser degree, Greek) is a school of precision, of strictness, of attentiveness. No form of intelligence is excluded. It concerns everyone and everyone is capable of benefiting from it." 16

${ }^{11}$ Lowe 2012, argument No 5. A short version of this argument may be found in a well-known bumper sticker: "Is your English in ruins, take Latin!" (cf. Moore n.d.: 2).

${ }^{12}$ Fuhrmann 1976: 78.

${ }^{13}$ Lowe 2012, argument No 7.

${ }^{14}$ See Goethe, Zahme Xenien (1987: 91); there are two precedent verses: "Das mußt du als ein Knabe leiden, / daß dich die Schule tüchtig reckt" ("A child must suffer being mentally stretched and taunted by lessons, for mental acuity is hidden in the sheath of ancient languages"). Goethe's point of reference in these verses is a statement by Luther on Hebrew, Ancient Greek and Latin as the three canonical languages of the gospel.

${ }^{15}$ See Maier (2008: 34), quoting Fuhrmann (1976 : 13), on Latin being a mental fitness trail ("ein Trimm-Dich-Pfad des Gehirns").

${ }^{16}$ Drillon 2016, argument No 5: "Le latin (et le grec, dans une moindre mesure) est une école de précision, de rigueur, d'attention. Aucune forme d'intelligence n'est exclue, tout le monde est concerné et capable d'en tirer profit." See also Anonymous (n.d.) argument No 5: "Faire du latin 
This alludes to the fact that, in addition to such cognitive-oriented argumentations, an even more social aspect has at last appeared in recent times: the integrative effect of Latin. This is based on specific experiences within the experience of a school environment, as the study of Latin is not necessarily an elitist affair: In 2014 in France, some 51\% of all students learning Latin came from more disadvantaged social strata. ${ }^{17}$ By promoting linguistic-grammatical competence as well as a more focused learning behavior, Latin lessons are often able to compensate for social — and cultural-linguistic - differences. Pioneer projects with this emphasis - in Paris or Berlin, for example - could produce great results. ${ }^{18}$ Structurally, Latin instruction thus fulfills a similar function as had already been observed in the Latin-speaking rhetoric school, which was established in Rome around $90 \mathrm{BC}$ in the face of opposition from the ruling class. Through education, it created opportunities for participation in the res publica and thus encouraged social mobility. ${ }^{19}$

\section{III}

Even if many arguments are immediately clear and the outlined instrumental function of Latin seems well-attested by experience and surveys, they still do not really answer the question regarding its purpose. For beyond the verification of data and statistics, it remains to be clarified within the group of educational goals and teaching subjects which rank should even be given to values such as the better understanding of one's own language, the facilitation of learning other languages or the advancement of more cognitive standards.

In comparison to specific practical requirements profiles, the fact that this in no way concerns secondary needs - that to begin with are at best justified by idealizing educational concepts - can be clarified by a consideration of media history. The research projects of recent decades have in many cases determined the development stimulus that was triggered by the introduction of writing and the transition from orality to literacy, and in doing so have shown the unavoidable long-term impact that this evolution in media has brought about. ${ }^{20}$ Overall, a broad consensus has been established that reading and writing are key instruments of culture.

aide à acquérir de la rigueur et de la précision: ce sont là des qualités essentielles tant pour les littéraires que pour les scientifiques."

${ }^{17}$ Drillon (2016) in his sixth argument also points out the potential of Latin as a social equaliser and the two-fold effect of this sphere of equal opportunities: "Donc, d'un côté, l'étude des langues anciennes égalise les chances de réussite scolaire et, de l'autre, elle maintient les riches dans les établissements publics."

${ }^{18}$ Cf. reports by Wiegel (2015: 3) and Brause (2018: 8).

${ }^{19}$ Schmidt 1975.

${ }^{20}$ A comprehensive summary is provided by Günther and Ludwig (1994-1996). 
Now, digitization, which began at the end of the last century, has brought with it an enormous quantitative increase in reading and writing activity. To an unforeseen extent, print today permeates even the everyday life of people who are further removed from this medium. The unprecedented increase in the immediate availability of information through the Internet, as well as the increase in the amount of communication activities, which entails digital media and undergoes further intensification through the social media networks, would have been inconceivable with the conventional writing technology. And what is true for the private domain is no less applicable to the work environment, whose digitization is fairly new and where we can expect the gradual replacement of conventional face-to-face interactions with written communication.

With such a quantitative increase, the conceptual framework for the written word is also transformed: in terms of quality, it is changing. Not least, the conventional validation und verification authorities no longer have any legitimacy; the worldwide debate over "fake news" may have provided a foretaste of this. All of this presents unforeseen challenges in the treatment of the written word as a carrier of information, messages, intentions, and concepts. Such being the case, the practical handling of written language is more than ever a key requirement, with respect to both the individual and society as a whole. This is because technical progress is a challenge that cannot be confined to the purely technological side of optimizing the medium. To a greater degree, it also transforms the user profile in a way that complements it: it increases the demand for the ability to analyze statements, to decipher complex issues, and to handle information with reliable and independent judgment.

Educational institutions have yet to come up with a conclusive response to these changes; at best, there is certainty that this will be a more long-term process. Some time ago, Stanford political scientist Hans N. Weiler, for many years also director of the International Institute for Educational Planning at UNESCO in Paris, made an impassioned plea for the development of modern information and communication technologies, arguing that they would inevitably bring about a sustainable change both in concept and in the practice of education. The "task of extraordinary and no less than historic significance" consists in "providing people with the analytical, critical and normative skills they need for the competent and responsible handling of this new world of boundless information." ${ }^{21}$ As "in contrast to the well-ordered, presorted knowledge world of the classical educational tradition equipped with evaluative markers, it is characterized by the relative influence of the increasingly cybernetic knowledge world on the development of

21 "Menschen mit den analytischen, kritischen und normativen Fähigkeiten auszustatten, die sie für den souveränen und eigenverantwortlichen Umgang mit dieser neuen Welt der grenzenlosen Information benötigen, ist eine Aufgabe von außerordentlicher und geradezu historischer Bedeutung" (Weiler 2009: 94). 
people through the striking absence of order, structure and evaluation." ${ }^{22}$ Since scientifically proven knowledge has claimed prima facie the same status as old wives' tales and completely fabricated assertions, the information available in cybernetic space has become "in a fundamental sense, questionable". 23

These trenchant observations make it clear why the extent to which students are trained to read carefully and accurately is highly topical. Now, the description of the analytical cognitive skills, their advancement being attributed to Latin in instrumental-functional argumentations, shows a remarkable overlap with the requirement profile developed by Weiler. This is by no means a coincidence, as the exposure to writing and the written form is not something that is imposed on Latin externally. Rather, it forms an essential part of its own history. For many centuries, Latin has stood for the impartation and practice of written form norms. The early modern era, for example, is full of relevant debates in which both the categories of poetry and prose concern themselves with precisely these questions. ${ }^{24}$ The point of reference and precondition for this are the corresponding standardization processes that took place in Classical Rome during the first century BC. The exemplary role ascribed to Latin grammar today is thus in this respect only a later and more limited successor of Latin's former designated task of imparting the standards of an elaborate written form into the composition and decoding of texts.

\section{IV}

Among Weiler's recommendations for how to meet the challenges of the new knowledge world, there is a reference to the necessity of developing the skills required to judge this world in normative terms. This is directed against a tendency of dumbing-down and homogenization that is recognized as a danger of the now wide-open knowledge world. Special effort is therefore required when exposed to other cultures of knowledge, as it is up to us to prevent the "sacrifice of intrinsic value and the autonomy of knowledge traditions found in other cultures to the almighty globalization of knowledge." 25

22 "Im Unterschied zu der wohlgeordneten, vorsortierten und mit bewertenden Etiketten ausgestatteten Wissenswelt der klassischen Bildungstradition zeichnet sich die an relativem Einfluss auf die Entwicklung von Menschen immer weiter zunehmende kybernetische Wissenswelt durch eine eklatante Abwesenheit von Ordnung, Struktur und Bewertung aus" (Weiler 2009: 96).

${ }^{23}$ Ibid.

${ }^{24}$ The $16^{\text {th }}$ century debate on Cicero as well as the discussion of preference for Homer or Virgil throughout so many centuries are central examples of this long-standing influence; see Robert 2007 and Vogt-Spira 2004.

${ }^{25}$ Weiler refers to protecting "den Eigenwert und die Eigenständigkeit von Wissenstraditionen in anderen Kulturen" (2009: 99-100). 
Here, the function that Claude Lévi-Strauss specifically ascribed to the teaching of ancient languages should again be recognized. ${ }^{26}$ Because of their characteristic position as intermediaries, they appear to be particularly wellsuited for it. On the one hand they are foreign enough to challenge our common expectations and habits; on the other hand, however, they are so strongly interwoven with the present that historical connections and familiar problems are rediscovered, albeit with different answers. ${ }^{27}$ This is because from a longterm perspective, Latinity belongs in either case to the key factors that have shaped modern-day Europe. ${ }^{28}$ Recently the Oxford Italianist and comparativist Nicola Gardini referred to it as no less than the "genetic code of the Occident." 29 Among the countless continuities, only Roman law is referred to here as an example. ${ }^{30}$ However, there is so much more than this: even concepts that today claim universal legitimacy are indebted to Latin culture. Examples spreading from Rome include human dignity (dignitas hominis) or a norm such as fides ("faith and constancy of the agreed upon"), which by no means constitutes a fundamental value in all cultures.

Why is it necessary, however, to know about these connections? The Italian cultural anthropologist and philologist Maurizio Bettini has asked the counter question of what world would be like without any knowledge of Latinity: what would happen if we stopped reading the Latin classics, and as a result, the flow of cultural memory linking us to Ancient Rome was interrupted? ${ }^{31}$ With this, as Bettini points out, the thread would also be cut that connects us - by means of these texts - to all those from past centuries who have scooped from this same river as part of their own cultural endeavor. Would we stop reading The Aeneid or other classics of similar significance, would we not only lose close

${ }^{26}$ See n. 4.

${ }^{27}$ Uvo Hölscher (1994) coined the well-known term of Latin and Ancient Greek being "das nächste Fremde" - the closest distance to modern life.

${ }^{28}$ This may easily be seen in book titles by Büchner (1978) or Fuhrmann (2001). The notion of Latin being one of the pillars of European culture has also been expressed in didactics more than once, for example by Fuhrmann (1976; see supr. n. 12), who gives the heading "Latein als Schlüsselfach der europäischen Tradition" to a chapter in his book (68). A similar, though less stimulating metaphor is used by Maier "Latein - Fahrstuhl zu den Wurzeln Europas" (2008: 47). Lowe lends an American perspective to the concept: "Latin is the language of Western civilization" (2012; see supr. n. 11, here argument No 10).

${ }^{29}$ Gardini, who authored the monography Viva il latino. Storie e bellezza di una lingua inutile (2016), coined this metaphor in an interview on $29^{\text {th }}$ July 2016: "Il latino è il codice genetico dell'Occidente; se vogliamo, pure il suo sistema immunitario, ovvero, per rimanere nella metafora biologica, la fonte prima del principio di identità" and surmised: "Conoscere il latino è importante quanto conoscere la riproduzione delle cellule o la fisica quantistica" (https://www.illibraio.it/ studio-del-latino-376867/).

${ }^{30}$ Wieacker calls Roman law a connection tying the whole occident together: vinculum quo totus occidens continetur (1978: 84).

${ }^{31}$ Bettini 2017: 49-50. 
contact with the Roman world, but with everyone who came after, to all those intellectual creations that were nourished by a dialogue with antiquity? We lose Virgil, we inevitably lose-and this is mutatis mutandis transferable to other European cultures - even Dante, and then in turn those who engage with his work: a chain continuing into the present. Bettini refers to this as a radical change of the cultural encyclopedia that in a sense is like a change in the alphabet.

The crucial point is that it is not only about the ancient world as such, rather, it is also about the diverse interdependencies and linkages that have shaped Europe throughout its history and continue to the present day. Such continuities and transformations have been increasingly taken into account in recent decades, and it is a field of research that is far from exhausted. But regardless of a broad consensus over the fact that various national cultures have been receptive of antiquity's contributions, the question still remains as to what significance should be ascribed to such receptivity. Or, to take up our central question: to what extent does knowledge of Latin with respect to these cultural connections answer a present-day need?

From this territory, which touches on the fundamental questions of cultural self-understanding, only one point of interest is singled-out below: Latin literature after the end of the Roman Empire, in particular the so-called Neo-Latin literature. According to a well-known projection, the amount of late-antiquity Latin texts, in a rough estimate, is at least ten thousand times larger than the mass of texts that have been passed down from Roman antiquity. Indeed, a substantial portion of these are archival and functional texts - the consequence of Latin's central position as a means of communication well into the $18^{\text {th }}$ century-yet in addition to this, there is a large number of texts that are literary in a narrower sense. In each European country in the $16^{\text {th }}$ century, production in the Latin language was more extensive than that of the national language, in some cases even longer. The Latin tradition in Poland and Hungary, for example, is especially far-reaching. ${ }^{32}$

At the same time, however, it is not Latin literary production as such that is decisive. Rather, it is the fact that it stands parallel to the respective vernacular literature and interacts with it: only the vernacular and Latin-speaking literatures together form the corpus of the respective national literature. The Latin-language literature is therefore a comprehensive component of each country's respective national literature and culture. Not infrequently, the authors themselves wrote in both registers and in doing so composed first-rate works. There are still many discoveries to be made, as the canonization processes of the modern era were one-sidedly oriented toward vernacular literatures. This, however, changes nothing about Latin's close affiliation to the respective national cultures. One could almost say that the presence of Latin is an indicator of how far a country's cultural memory goes back and the degree of its distinctiveness.

\footnotetext{
${ }^{32}$ See Leonhardt 2009: 2-5, 221.
} 
Up to this point, we have shifted the focus to the issue of tradition continuities that identify Latin culture as a fundamental component of European culture. However, it also challenges the perception of alterity; as much about ancient Rome is different and foreign. It is not without reason that Lévi-Strauss mentioned that learning Greek and Latin allows access to an intellectual method that he refers to as ethnography. ${ }^{33} \mathrm{He}$ assigns to it an important task. This is because no civilization can itself think if it does not have access to others that can serve as a point of comparison. Here he also sees the essence of the rediscovery of Greco-Roman antiquity in the Renaissance. In ancient literature, it not only rediscovered forgotten concepts and methods, but also the means of providing a perspective of one's own culture via the comparison of contemporary views with those of other times and places. Weiler, too, in the face of the unifying presentism promoted by new media, declared the ability to grasp and decipher a foreign culture in the face of present-day challenges as a highly topical key skill. ${ }^{34}$

In this respect, Latin literature and culture now has an extraordinary dual function that lies between proximity and foreignness. Every dialogue with a Roman author-whether it is the humorous Plautus, the philosophic Lucretius, the epic Virgil, or the lyrical Horace - makes clear the inherent challenges of achieving a precise understanding of a Latin text. In addition to the lexical side, it is really only revealed within a historical and epistemological context. An intensive reading, as a result, constitutes an "alterity training" par excellence. ${ }^{35}$

This alterity training is not least encouraged by the abundance of information that enables a reconstruction of the foreign horizon, or sometimes even just triggers the perception of foreignness. Quite often it is a first step in acknowledging that a seemingly familiar concept in reality means something that exists within completely different contexts for reference and reasoning. This is because the continuity of Latin culture entails that, on the other hand, many things again become closer to us and seem as though they are immediately accessible.

The intellectual instruments for perceiving alterity, encouraged by the study of Latin literature in its complex inherent laws, thus signifies a perspectivization on two counts. It not only opens up the possibility of discovering alternatives to one's own habits, but at the same time allows these to be discerned within their own specific conditions. Not taking information for granted has always been a prerequisite for innovation. As such, making the foreign and complex world of a

\footnotetext{
${ }^{33}$ See n. 4.

${ }^{34}$ See n. 25.

${ }^{35}$ Bettini (2017: 81-94) calls this the "alterità degli antichi."
} 
Latin text accessible is, from an intellectual standpoint, not linked with the static adherence to tradition, but with openness and dynamism. ${ }^{36}$

\section{VI}

Ovid noted in his Fasti that we praised the ancients, yet lived in the present; his Solomon-like solution was that we hold both in high esteem. ${ }^{37}$ The United States Secretary of Defense in 2003, Donald Rumsfeld saw this differently. In the course of disputes between Europe and the US, he spoke of "old Europe": a buzzword that dominated the European media and triggered emotions, as it clearly hit a nerve. "Old" was decidedly intended to be pejorative, in the sense of "outdated, backward, anachronistic"; indeed, it was really supposed to evoke the notion of weakness associated with old-age that makes one incapable of action; the young, dynamic and thus forward-thinking America constituting its antithesis. However, the debate took a remarkable course by which Rumsfeld later tried to correct the offensive tone of his statement: He had meant "old" not as an insult, but as a caress in the form of an honorary title.

This semantic range in which the word "old" is used yields something that in its essence constitutes Europe - and the fact that even an American secretary who by no means is known for making sharp distinctions did this, indicates that it is a deeply-rooted notion. This is not just because Europe is old in the sense of age. Rather, the ancient constitutes in its almost three-thousand-yearold writing culture a significant object for reflection. The epithet "old" oscillates in its evaluation precisely on that scale of negative and positive accentuation: between "archaic, outdated" on the one hand and "old" as a mandatory reference point - one that demands authority — on the other.

This by itself would certainly not be anything extraordinary. Instead, what is decisive is that throughout the course of European history, the initiative has repeatedly been taken to situate and update the ancient as a point of orientation for the present, as a norm or even as an ideal; to thus make the ancient a fruitful option for the future. If the ancient becomes normative and is ascribed

\footnotetext{
${ }^{36}$ Taking an interest in literature and culture in and of itself is a central prerequisite to achieving this, which necessitates reading the source material, for example works by Cicero, Virgil or Horace, in its original language. Moore opposes the notion that translations are a sufficient basis for learning about ancient Latin and Greek culture by conceiving of a familiar experience (n.d.: 3): "One cannot compare the impression made by the original works of Monet and Renoir to the poster prints in the gift shop. The brush strokes of the artist, careful and attentive details, and hues of colour playing or contending with one another are lost upon the beholder. So it is with language. The beauty of each carefully chosen word placed in its proper position is lost to the reader when transferred to the canvas of another language."

${ }^{37}$ Ov. Fast. 1, 225-226.
} 
an exemplary importance, it gains a function that we have grown accustomed to referring to it as classical. Indeed, Europe thus distinguishes itself in that it virtually has a series of classicisms, in which the Greco-Roman antiquity in particular has been repeatedly functionalized in this way as an option for the future. Antiquity practically serves as a vehicle for legitimizing modernization. ${ }^{38}$

In fact, the dimension of the future and the question of sustainability is a dominant category in public discourse - this is truer than ever before and is rooted in a globalized world in which an increasing interdependence increases the pressure to compete and fight over the distribution of resources. One of the main tasks identified some time ago at a series of European higher education forums held at the German-Italian Centre for European Excellence Villa Vigoni was that educational institutions should undertake to focus on the future and anticipate what was in store for it. ${ }^{39}$ In terms of content, there were some interesting trends to be observed. The buzzword of knowledge society that for a long time shaped discourse has taken a back seat; the impartation of knowledge appears to be too mechanistic. Having greater priority instead are strengthened qualitative characteristics such as the ability to solve problems, critical-thinking skills, independence, even education right up to personal development and judgement. The latter does not by any means remind us of the training of the iudicium, which for centuries was a core value imparted into the practice of Latin literary culture. In any case, the symposia were marked by a broad consensus on the indispensability of education and cultural competence. Qualities that are recognized as the basis for European success in global competition. The emphasis with which these propositions occurred is quite remarkable.

If one now tries to summarily define the function of Latin against this background, two fundamentally different perspectives remain to be distinguished. From an individual standpoint, Latin is by no means the only way to face challenges like those outlined above; there is no such silver bullet for them anyway. Nonetheless, whoever learns Latin is well-equipped for the future. Socio-culturally, however, a sufficient presence of knowledge of antiquity and Latin's continuity is indispensable for a nation's cultural memory. Every civitas, be it a Greek polis of antiquity or the modern nation-state, seeks to acquire and shape knowledge about the past, since identity is never nourished by the pure present, but by the interpretation of the past. From this, in various European countries, Latin culture constitutes one of the most significant and formative

${ }^{38}$ This type of discourse may be traced back to the Romans themselves, who revered Ancient Greek literature and culture as classical and made it their point of reference in artistic aemulatio and imitatio. This contest with classical Greek culture necessitated intense reflection as well as meditation on Roman national identity. Thus the effort of grappling with a different culture made Roman art and literature a reference point and model for later instances of European classicism.

${ }^{39}$ See Vogt-Spira 2011. 
strands. Yet the fact that Latin has been able to maintain such extraordinary charisma is not least due to the fact that it has produced key works that could be reread and read differently at any time. ${ }^{40}$

\section{BIBLIOGRAPHY}

Bettini 2017: Bettini, M. 2017. A che servono i Greci e i Romani. Torino: Einaudi.

Büchner 1978: Büchner, K. (ed.). 1978. Latein und Europa. Traditionen und Renaissancen. Stuttgart: Reclam.

Brause 2018: Brause, C. 2018. "Neuköllns Eliteschule.” DIE WELT 20. März 2018, p. 8.

Drillon 2016: Drillon, J. 2016. "10 bonnes raisons d'apprendre le latin." Accessed May 31, 2019. http://pileface.com/sollers/IMG/pdf/10\%20bonnes\%20raisons.pdf

Fuhrmann 1976: Fuhrmann, M. 1976. Alte Sprachen in der Krise? Stuttgart.

Fuhrmann 2001: Fuhrmann, M. 2001. Latein und Europa. Geschichte des gelehrten Unterrichts in Deutschland von Karl dem Großen bis Wilhelm II. Köln: Dumont.

Gardini 2016: Gardini, N. 2016. Viva il latino. Storie e bellezza di una lingua inutile. Milano.

Goethe 1987: Goethe, Johann Wolfgang. 1987. Sämtliche Werke nach Epochen seines Schaffens (Münchner Ausgabe), Bd. 9: Epoche der Wahlverwandtschaften 1807-1814, ed. Ch. Siegrist, Hans J. Becker u,a., München.

Günther, Ludwig 1994-1996.

Günther. H. and O. Ludwig (eds.). 1994-1996. Schrift und Schriftlichkeit / Writing and Its Use. Ein interdisziplinäres Handbuch internationaler Forschung / An Interdisciplinary Handbook of Inernational Research, 2 vol. Berlin-New York.

Hölscher 1994: Hölscher, U. 1994. Das nächste Fremde. Von Texten der griechischen Frühzeit und ihrem Reflex in der Moderne. München.

Jauch 2006: Jauch, G. 2006. "Latein geht Umwege.” Der Spiegel 2006, Nr. 14, p. 146.

Jaumann 1999: Jaumann, H. 1999. "Das dreistellige Translatio-Schema und einige Schwierigkeiten mit der Renaissance in Deutschland." In Rezeption und Identität. Die kulturelle Auseinandersetzung Roms mit Griechenland als europäisches Paradigma. Ed. by G. Vogt-Spira and B. Rommel, 335-349. Stuttgart.

Leonhardt 2009. Leonhardt, J. 2009. Latein. Geschichte einer Weltsprache München.

Anonymous. n.d. "Voici quelques bonnes raisons d'apprendre le latin aujourd'hui." Accessed May 31, 2019. http://webetab.ac-bordeaux.fr/college-marguerite-navarre/fileadmin/0640607 M/fichiers_publics/info6_latin.pdf

Lévi-Strauss 1973: Lévi-Strauss, C. 1973. Anthropologie structurale deux. Paris.

Lowe 2012: Lowe, C. “Top 10 Reasons for Studying Latin." Classical Christian Education for All Ages. Accessed June 22, 2019. file://Users/administrator/Desktop/Texte/Materialien\%20 und $\% 20$ Lit.vz/Latein/Top\%2010\%20Reasons\%20for\%20Studying\%20Latin \%20\%7C\%20 Memoria\%20Press.webarchive

Maier 2008: Maier F. Warum Latein? Zehn gute Gründe. Stuttgart.

Moore n.d.: Moore, K. n.d., "Why Latin?" Classical Academic Press. Accessed May 31, 2019. https://classicalacademicpress.com/wp-content/uploads/2016/03/why_latin.pdf.

Robert 2007: Robert, J. 2007. "Audite simiam Ciceronis: Nachahmung und Renaissancepoetik ein systematischer Aufriß." In Maske und Mosaik. Poetik, Sprache, Wissen im 16. Jahrhundert. Ed. by J.-D. Müller and J. Robert, 75-127. Münster.

Scaliger 1994-2011: Scaliger, Julius Caesar. 1994-2011. Poetices libri septem. Sieben Bücher über die Dichtkunst. Unter Mitwirkung von M. Fuhrmann hrsg., übers., eingel. und erl. von L. Deitz und G. Vogt-Spira, 6 Bde., Stuttgart-Bad Cannstatt.

\footnotetext{
${ }^{40}$ I would like to thank Bradley Alan Schmidt for the English translation.
} 
Schmidt 1975: Schmidt, P.L. 1975: "Die Anfänge der institutionellen Rhetorik in Rom.” In Monumentum Chiloniense. Festschrift für Erich Burck. Ed. by E. Lefèvre, 183-216. Amsterdam.

Stroh 2007: Stroh W. 2007. Latein ist tot, es lebe Latein: Kleine Geschichte einer großen Sprache. Berlin.

Vogt-Spira 2003: Vogt-Spira, G. 2003. "La formazione del concetto di arcaico. Omero e Virgilio nel Rinascimento tra storia della letteratura e critica letteraria." Atti e memorie della Accademia Petrarca di lettere, arti e scienze 65: 423-448.

Vogt-Spira 2011: Vogt-Spira, G. 2011. Challenges of Global Competition in Tertiary Education. Trieste: EUT Edizioni Università di Trieste.

Weiler 2009: Weiler, H.N. 2009. "Bildung im Zeitalter ihrer technischen Reproduzierbarkeit." In Bildung? Bildung! 26 Thesen zur Bildung als Herausforderung im 21. Jahrhundert. Ed. by A. Schlüter and P. Strohschneider, 93-100. Berlin.

Wieacker 1978: Wieacker, F. "Vom Lebenswert des römischen Rechts." In Latein und Europa. Traditionen und Renaissancen. Ed. by K. Büchner, 84-99. Stuttgart.

Wiegel 2015: Wiegel, M. 2015. "Sokrates und Seneca in der Banlieu." Frankfurter Allgemeine Zeitung 28. November 2015, p. 3.

\section{LATEIN ALS ZUKUNFTSOPTION. EINIGE ÜBERLEGUNGEN ZU LATEIN UND LITERALITÄT IM DIGITALEN ZEITALTER}

\section{Zusammenfassung}

Der Beitrag verfolgt die Frage, inwiefern Latein den Bedürfnissen der aktuellen Gegenwart Rechnung tragen kann, so daß seine Pflege einen wohlbegründeten Platz in den europäischen Ländern und Gesellschaften hat. Er geht von der Beobachtung aus, daß Latein vielfach ein ,Mehrwert‘ zugewiesen wird, wie etwa Alter-itätserfahrung, kognitives Training, Einsicht in Sprachstrukturen oder eine sozial integrative Wirkung, wobei diese funktionalen Begründungsmuster bemerkenswerterweise nicht an bestimmte Nationalkulturen gebunden sind. Der Beitrag hält dies jedoch noch nicht für ausreichend. Eine zentrale Herausforderung wird in der Digital-isierung und der modernen kybernetischen Wissenswelt gesehen mit ihrem enormen quantitativen Zuwachs an Lese- und Schreibtätigkeit, der komplementär auch das Nutzerprofil verändert: ein Wandel, auf den die Bild-ungsinstitutionen noch keine schlüssige Antwort gefunden haben. In diesem Rahmen erhält die Leistung des Latein, Standards einer elaborierten Schriftlichkeit im Verfassen und Entschlüsseln von Texten zu vermitteln, eine wichtige Funktion. In einem weiteren Schritt wird darauf aufmerksam gemacht, daß die Latinität einer der Schlüsselfaktoren ist, die das heutige Europa geprägt haben, und vermerkt, daß die neulateinische Literatur übergreifend Bestandteil der jeweiligen nationalen Literatur und Kultur ist. Zum Schluß wird der Blick auf die alte europäische Praxis gelenkt, die Antike nachgerade als Vehikel zur Legitimation von Modernisierung zu benutzen. 